Discussion Paper No. 12-006

Environmental Innovation and Employment Dynamics in Different Technology Fields An Analysis Based on the German Community Innovation Survey 2009

Jens Horbach and Klaus Rennings

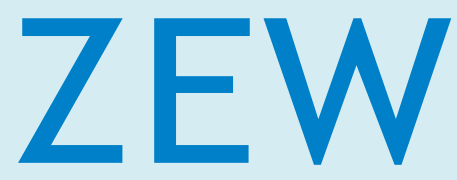

Zentrum für Europäische Wirtschaftsforschung $\mathrm{GmbH}$

Centre for European Economic Research 
Discussion Paper No. 12-006

\section{Environmental Innovation and} Employment Dynamics in Different Technology Fields -

\section{An Analysis Based on the German Community Innovation Survey 2009}

Jens Horbach and Klaus Rennings

Download this ZEW Discussion Paper from our ftp server:

http://ftp.zew.de/pub/zew-docs/dp/dp12006.pdf

Die Discussion Papers dienen einer möglichst schnellen Verbreitung von neueren Forschungsarbeiten des ZEW. Die Beiträge liegen in alleiniger Verantwortung der Autoren und stellen nicht notwendigerweise die Meinung des ZEW dar. 


\section{Non-technical Summary}

In a controversial political debate, new environmental technologies are often regarded as a job creator or - due to strict environmental policy - as a job killer. A detailed analysis for these employment effects for different environmental innovation fields might shed light on this debate but, unfortunately, there are only few corresponding studies available. We use the 2009 wave of the German part of the Community Innovation Panel (CIS) allowing for such an analysis at the firm level. The main focus of the paper lies on the analysis of the adaptation behavior of firms with respect to the relationship of employment and (environmental) innovation. Our econometric analysis shows that innovative firms in general are characterized by a significantly more dynamic employment development. Especially the realization of environmental process innovations leads to a higher employment within the firm. The theoretical background of this finding is that cost savings induced by process innovations lead to an improved competitiveness of the firm. This has a positive effect on demand and thus increases also employment.

A more detailed analysis by different environmental innovation fields shows that material and energy savings are positively correlated to employment because especially these process integrated measures help to increase the profitability and competitiveness of the firm. On the other side, air and water process innovations that are still dominated by end-of-pipe technologies, however, have a negative effect on employment.

In a nutshell, the employment effects of the introduction of cleaner process technologies seem to be more advantageous within a firm compared to more end-of-pipe oriented technologies. 


\section{Das Wichtigste in Kürze}

In der politischen Diskussion gelten neue Umwelttechnologien einerseits als Chance für neue Arbeitsplätze, andererseits wird behauptet, dass eine strenge Umweltpolitik Arbeitsplätze vernichtet. Eine genaue Analyse dieser Beschäftigungseffekte, in der nach unterschiedlichen Umweltinnovationsfeldern unterschieden wird, könnte diese Debatte erhellen. Leider gibt es bislang nur wenige Studien diesbezüglich. In der vorliegenden Arbeit werden die deutschen Daten des europaweiten Innovationspanels, des Community Innovation Panel (CIS), des Jahres 2009 ausgewertet, die eine solche Analyse auf Unternehmensebene ermöglichen. Im Mittelpunkt steht dabei die Analyse des Anpassungsverhaltens von Unternehmen im Hinblick auf den Zusammenhang zwischen Beschäftigung und (Umwelt-) Innovationen. Unsere ökonometrische Analyse zeigt zunächst, dass innovative Unternehmen eine wesentlich dynamischere Beschäftigungsentwicklung aufweisen als Unternehmen, die im Untersuchungszeitraum keine Innovationen durchgeführt haben. Insbesondere die Realisierung umweltbezogener Prozessinnovationen führen auf Unternehmensebene zu einer höheren Beschäftigung. Aus theoretischer Sicht ist dieses Ergebnis darin begründet, dass Umweltprozessinnovationen zu Kostensenkungen führen, die wiederum eine Verbesserung der Wettbewerbsfähigkeit induzieren. Die daraus resultierende Mehrnachfrage führt dann zu mehr Beschäftigung.

Eine detaillierte Analyse nach einzelnen Umweltbereichen zeigt, dass Material- und Energiesparmaßnahmen, die als prozessintegrierte Maßnahmen in besonderer Weise die Profitabilität und die Wettbewerbsfähigkeit eines Unternehmens verbessern, zu einer Steigerung der Beschäftigung führen können. Auf der anderen Seite haben Innovationen im Bereich der Luftund Wasserreinhaltung, wo End-of-Pipe-Maßnahmen dominieren, einen negativen Einfluss auf die Beschäftigung. 


\title{
Environmental Innovation and Employment Dynamics in different Tech- nology Fields - An Analysis based on the German Community Innovation Survey 2009
}

\author{
Jens Horbach \\ University of Applied Sciences Augsburg \\ Klaus Rennings \\ Centre for European Economic Research (ZEW), Mannheim
}

\begin{abstract}
The employment effects of environmental technologies are in the focus of politicians but there are only few studies analyzing these effects for different environmental innovation fields. We use the 2009 wave of the German part of the Community Innovation Panel (CIS) allowing for such an analysis at the firm level. The main focus of the paper lies on the analysis of the adaptation behavior of firms with respect to the relationship of employment and (environmental) innovation. We use an endogenous switching regression approach to take the simultaneous character of innovation activities and employment demand into consideration. Our econometric analysis shows that innovative firms in general are characterized by a significantly more dynamic employment development. Especially the realization of environmental process innovations leads to a higher employment within the firm. The theoretical background of this finding is that process innovation induced cost savings improve the competitiveness of firms. This has a positive effect on demand and thus also increases employment. A more detailed analysis by different environmental innovation fields shows that material and energy savings are positively correlated to employment because they especially help to increase the profitability and competitiveness of the firm. On the other side, air and water process innovations that are still dominated by end-of-pipe technologies have a negative impact on the employment development.
\end{abstract}

JEL: Q52, Q55, J49, C25

Keywords: Employment, Environmental Innovation, Innovation Behaviour 


\section{Introduction}

In a controversial political debate, environmental technologies are often regarded as a job creator or - due to strict environmental policy - as a job killer. The relevant literature, however, has shown so far that the effects are quite small (Horbach 2010, Rennings and Zwick 2002, Pfeiffer and Rennings 2001). While the knowledge of employment effects in general has improved due to this empirical evidence, the heterogeneity of environmental technologies regarding employment is still largely unknown.

The paper tries to fill at least partially this gap by using the new Community Innovation Panel of 2009 (CIS 2009) which allows differentiating between different types of environmental technology areas such as process and product innovation and further distinguishing between e.g. material and energy savings, air emissions or recycling.

Due to the data basis, our analysis is restricted to the employment behavior of firms but it seems to be highly interesting to analyze the adjustment processes triggered by ecoinnovations. It is therefore not the aim to find out if eco-innovations are advantageous for the employment of the whole economy on a macroeconomic level but we are interested in the employment adaption behavior of firms.

Besides a descriptive analysis, we use econometric methods to analyze the relationship between eco-innovation and employment. Within a firm, the planning and realization of an ecoinnovation often requires a simultaneous decision on employment adjustment. The simultaneous nature of the decision on increasing or decreasing employment requires the application of adequate econometric methods such as the use of an endogenous switching model (see Section 4).

The paper is organized as follows: Section 2 analyzes the employment effects of ecoinnovation from a theoretical perspective and gives an overview of the main empirical results in the literature. In Section 3, descriptive results from our data basis of the CIS 2009 are presented linked to the macroeconomic background of the respective time period. Our econometric results for the relationship between eco-innovation and employment are discussed in Section 4. A summary (Section 5) finalizes the paper. 


\section{Employment effects of eco-innovative process and product innovations for different technological areas - theory and empirical perspective}

The relationship between (eco-) innovation and employment within a firm strongly depends on the nature of innovation, especially between process and product innovation (see Pfeiffer and Rennings 2001 and Table 1). Furthermore, the distinction between direct and indirect employment effects that differ for product and process innovations is important.

Table 1: Direct and indirect employment effects of eco-innovation at the firm level

\begin{tabular}{|l|l|}
\hline Process Innovation & Product Innovation \\
\hline $\begin{array}{l}\text { Direct employment effects: } \\
\text { masitive: Introduction of end-of-pipe measures }\end{array}$ & $\begin{array}{l}\text { Positive: Higher demand for the firm's } \\
\text { new products }\end{array}$ \\
$\begin{array}{l}\text { Negative: Higher costs because of implementa- } \\
\text { tion of end-of-pipe technologies (e.g. new air } \\
\text { emission filters) }\end{array}$ & Indirect employment effects: \\
$\begin{array}{l}\text { Indirect employment effects: } \\
\text { Negative: Substitution of more conven- } \\
\text { tional, less environmentally friendly } \\
\text { products (product innovation accompa- } \\
\text { savings) may lead to a higher competitiveness } \\
\text { (due to a higher productivity accompanied by a a } \\
\text { given output) and a higher demand }\end{array}$ & $\begin{array}{l}\text { Negative: Product innovation may cause } \\
\text { a monopolistic position of the firm lead- } \\
\text { ing to less output }\end{array}$ \\
\hline
\end{tabular}

Process innovations are often suspected to induce negative direct employment effects (see e.g. Harrison et al. 2008). This may be the case if process innovations lead to a higher productivity within the firm accompanied by a given output. However, higher productivity increases the competitiveness of firms and thus leads to positive indirect employment effects.

On the other hand, end-of-pipe process innovations may require additional staff (e.g. for the maintenance of a filter system) and thus lead to positive direct employment effects. The indirect effect, however, may be negative since end-of-pipe technologies lead to higher costs connected with a lower competitiveness and a decline of output and employment. The sign of the overall effect thus remains an empirical question. 
The employment effects of environmental product innovations also remain theoretically unclear. On the one hand, product innovations may induce new demand for the firm if they create completely new markets or if they substitute products of competitors. In this case, the effect for employment at the firm level is positive. On the macroeconomic level, the effect is not determined and depends inter alia on the labor intensity of the substituted products. Negative employment effects of product innovations may also arise because the introduction of the new product may cause a monopolistic position leading to a reduction of output (Hall et al. 2006).

In line with the famous Porter hypothesis (Porter and van der Linde 1995), cleaner technologies such as energy saving engines may induce lower costs leading to a higher competitiveness of the firm. The resulting higher product demand then may require more employees. Therefore, empirically, it seems to be very important to identify the type of process innovation when assessing its employment effects.

From an empirical point of view, there are many papers analyzing the general link between innovation and employment but relatively few analyses for the specificities of ecoinnovations.

Econometric studies on general innovation and employment rely on different methodologies. There are cross-sectional studies such as Entorf and Pohlmeier (1990) that cannot address the dynamic character of the relationship between innovation and employment. Most analyses use growth rates between two different points in time (e.g. RWI 2005, Peters 2005, Harrison et al. 2008). Other authors use panel data over a longer period of time and apply corresponding (dynamic) panel data models to analyze the data (e.g. van Reenen 1997, Smolny 1998, 2002, Smolny and Schneeweis 1999, Rottmann and Ruschinsky 1998, Piva and Vivarelli 2005, Lachenmaier and Rottmann 2007 and 2011).

Most of these studies in Germany, focussing on general innovations, found positive effects of product innovations on labour demand (see e.g. RWI 2005, Peters 2005, Smolny 1998, 2002, Piva and Vivarelli 2005, Zimmermann 2009). Similar results were detected for the UK (van Reenen 1997) and for France (Greenan and Guellec 2000) and in a comparative study for France, Great Britain, Germany and Spain based on harmonised data of the Community Innovation Panel (CIS) (Harrison et al. 2008).

In a recent analysis, Bogliacino and Pianta (2010) use a sectoral database including CIS data from 1994 to 2004 for eight European countries. Interestingly, they find different roles of innovation, wages and demand for employment across different types of industries. Further 
studies on the European level have been undertaken by Antonucci and Pianta (2002) and Pianta (2000).

Analyses on the employment effects of environmental innovations are still rare due to data problems. In general, these studies also detect positive effects of eco-innovations on employment (Bijman and Nijkamp 1988, Pfeiffer and Rennings 2001, Rennings and Zwick 2002, Harabi 2000, Rennings 2003). Rennings and Zwick (2002) find a small positive employment effect at the firm level. The positive effects relate to both product and service innovations. The other determinants of employment development in this study, including more than 1500 firms from five European countries, the market share as an innovation goal, innovation size and the strictness of environmental regulation, are significant for employment changes. Confirming our theoretical considerations, Pfeiffer and Rennings (2001) show that cleaner production is more likely to increase employment compared to end-of-pipe technologies. This result is confirmed by Rennings et al. (2004) where the econometric results show that product and service eco-innovations have a positive effect on the probability of an employment increase, whereas end-of-pipe measures lead to a decline. In a recent paper, Horbach (2010) confirms a positive influence of eco-product innovations on employment. The positive effects of eco-innovation seem to be larger compared to other non-environmental innovation fields. Especially with regard to employment effects of specific technology fields such as recycling, energy and resource efficiency, the total as well as the isolated direct and indirect employment effect are not well understood. Fortunately, our database of the Community Innovation Panel (CIS) 2009 allows such a technology-specific analysis.

Our empirical analysis based on the CIS is limited to the firm-level. Macroeconomic effects may be captured by adequate models such as Computable General Equilibrium (CGE) models but not on a firm data basis. However, since the size and direction of effects is unclear, survey data can explain the adaptation behavior of firms' employment demand with respect to ecoinnovation. That may be valuable to promote more realistic macroeconomic calculations of the employment effects of eco-innovation. 


\section{Data, descriptive results and the macroeconomic background (for the relevant time period 2006-2008)}

\subsection{Data}

Our study rests on a unique firm data set collected in the context of the Community Innovation Surveys (CIS) of the European Commission. Conducted for the CIS in 2009, a separate module on environmental innovations was introduced. An environmental innovation has been defined as "a new or significantly improved product (good or service), process, organisational method or marketing method that creates environmental benefits compared to alternatives. The environmental benefits can be the primary objective of the innovation or the result of other innovation objectives. The environmental benefits of an innovation can occur during the production of a good or service, or during the after sales use of a good or service by the end user." What follows is a list of environmental benefits that an environmental innovation could have produced either with the firm or from the after sales use of a product by the user for which surveyed firms should state whether this benefit has occurred or not.

The German CIS further developed this question in two respects. Firstly, firms reporting a certain environmental benefit were asked to assess whether this benefit was of high, medium or low importance in terms of reducing environmental impacts. Secondly, the list of potential environmental benefits has been enlarged to better distinguish different areas of environmental externalities and associated policies.

The German CIS of 2009 covers 7,061 firms in mining and quarrying, manufacturing, energy and water supply, and a large number of service sectors. The response rate was $26 \%$ both for manufacturing and services which is in line with comparable non-mandatory surveys. In order to control for a likely response bias between innovating and non-innovating firms, a nonresponse survey was performed, covering a stratified random sample of more than 4,800 nonresponding firms. This survey was conducted by telephone and revealed that the share of innovators among non-responding firms did not differ significantly from that of responding firms.

Furthermore, we also use data stemming from a telephone survey that the Centre for European Economic Research (ZEW) conducted in addition to the German CIS 2009. A subsample of 3,778 firms of the German CIS 2009 was considered, the response rate was $78 \%$ so that the answers of 2,952 firms are available. The firms were considered for the additional telephone survey if they 
- answered to the CIS questionnaire;

- had introduced an innovation from 2006 to 2008 with at least low environmental impacts in one or several environmental fields.

In contrast to the CIS questionnaire using the before mentioned scale of no, low, medium or high impact, the additional telephone survey only allowed a yes-no option to assess the environmental impacts of a firm's innovation. Therefore, only 1,294 firms out of the 2,952 firms confirmed having introduced environmental process or product innovations from 2006 to 2008.

\subsection{Descriptive results}

Our descriptive results show a dynamic development of employment in nearly all environmental technology fields. Especially firms with environmental process innovations are characterized by a much higher employment dynamic compared to all other innovative firms (see Table 2) confirming the results of Horbach (2010) based on the establishment panel of the Institute for Employment Research in Nuremberg. Following our descriptive results, the differences between the different environmental innovation fields do not seem to be significantly high. Firms that did not realize an innovation during 2006 to 2008 only show a small increase of employment (1.3\%).

Finding an adequate answer to the question if the introduction of a new eco-process or product increases employment requires an econometric analysis allowing to control for further variables such as size of the firm, market structure or demand (see Section 4).

An aspect that we may have to bear in mind when interpreting our results lies in the specific time period of the CIS 2009 data that only allow analyzing the employment development from 2006 to 2008. From a macroeconomic background, in Germany, the time period from 2003 to 2008 was characterized by an increase of employment of approximately $4 \%$ accompanied by a clear increase of productivity measured by the real GDP per employee of $5.1 \%$ (Statistisches Bundesamt 2011). Obviously, the German firms succeeded in improving their competitiveness by increasing their productivity e.g. by process innovations. The higher competitiveness then led to a high demand and allowed the firms to take on more employees. This process was supported by a sharp decline of real wages of approximately $4 \%$ from 2003 to 2008 - a development that has only been rarely observed in the post-world war history of Germany (Brenke 2009). 
Table 2: Employment development by different environmental technology areas from 2006 to 2008

\begin{tabular}{|l|c|c|}
\hline Introduction of innovations with environmental benefits within the firm 2006 to 2008 \\
\hline Environmental impact areas & $\begin{array}{c}\text { Employment development } \\
\text { from 2006 to 2008 in \% }\end{array}$ & $\begin{array}{c}\text { Number of } \\
\text { firms }\end{array}$ \\
\hline Reduced material use per unit of output & 7.3 & 1,107 \\
\hline Reduced energy use per unit of output & 7.9 & 1,245 \\
\hline Reduced $\mathrm{CO}_{2}$ emissions & 7.7 & 1,044 \\
\hline Reduced emissions of other air pollution & 8.9 & 706 \\
\hline Reduced water pollution & 7.9 & 698 \\
\hline Reduced soil pollution & 8.2 & 414 \\
\hline Reduced noise pollution & 9.2 & 679 \\
\hline Replacement of hazardous substances & 7.9 & 707 \\
\hline Recycled waste, water or materials & 8.8 & 1,133 \\
\hline \begin{tabular}{l|l|} 
Introduction of innovations with environmental benefits from using a firm's products 2006 to \\
2008
\end{tabular} & 6.0 & 1,240 \\
\hline Reduced energy use & 8.8 & 893 \\
\hline Reduced air, water, soil or noise emissions & 8.0 & 700 \\
\hline Improved recycling of products after use & 3,0 & 2054 \\
\hline Other innovators (no eco-innovation) & 7.1 & 4,158 \\
All innovative firms & 1,3 & 6,755 \\
\hline $\begin{array}{l}\text { Firms without innovations } \\
\text { All firms }\end{array}$ & 6.7 & \\
\hline * All firms with high or medium environmental impacts in the respective area are included. \\
The growth rates are weighted by the size of the firms. \\
\hline
\end{tabular}

Source: German CIS 2009

Next, we will present results of the telephone survey since they allow analyzing the employment effects of the most important innovation of the questioned firm. In fact, only $1.8 \%$ of the firms report a lower employment due to the main eco-innovation, 13.3\% report a higher employment, whereas for $85 \%$ of the questioned firms employment remains unchanged. Thus, the earlier finding of Rennings and Zwick (2002) of a small positive employment effect seems to be confirmed. Table 3 shows some examples for innovations with negative and positive employment effects. Especially energy saving measures seem to be accompanied by positive employment effects. 
Table 3: Examples for the employment effects of different environmental innovations

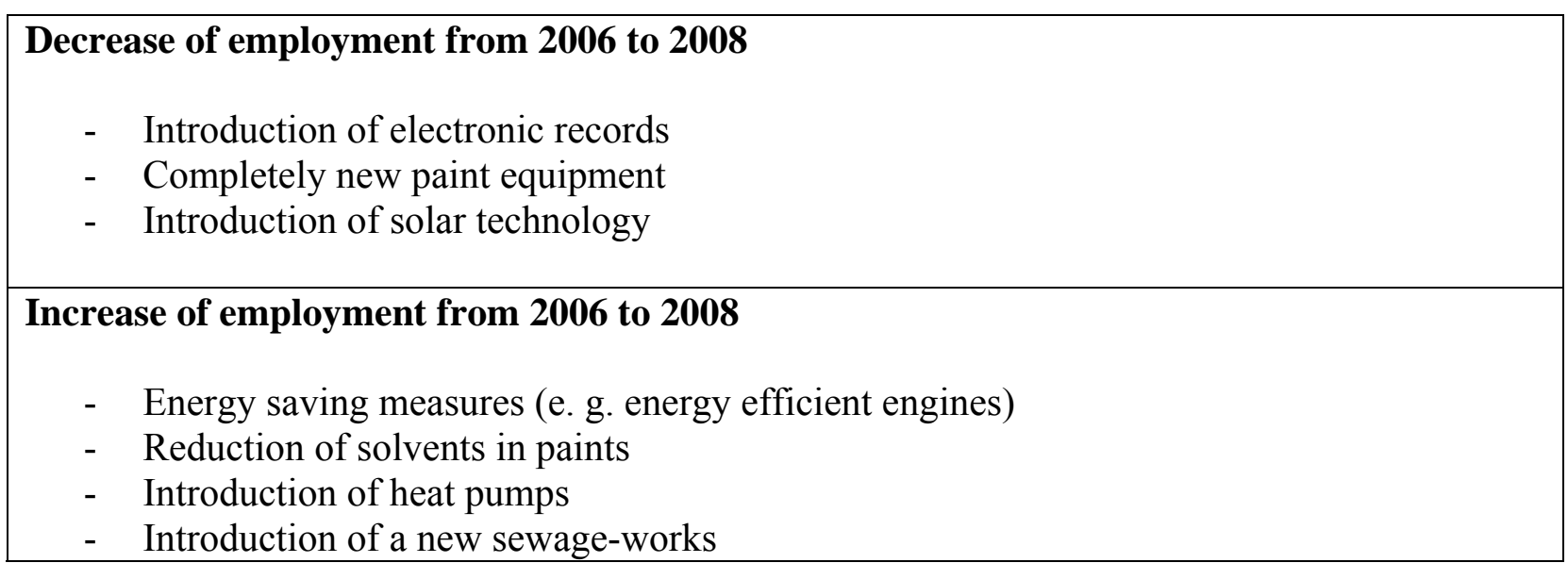

\section{Econometric analysis}

\subsection{Overall effects of (eco-) innovation on employment: an endogenous switching model}

The descriptive analysis in Section 3 shows a dynamic employment development for most of the environmental technology areas. Compared to other innovators, and especially noninnovators, the employment dynamics of eco-innovations seem to be over-proportionally high.

But in fact, a descriptive analysis is not suitable to explain causal relationships between innovation and employment. Furthermore, the analysis of this relationship is not trivial because, on the one hand, the decision of a firm to realize an innovation may cause the need of an adaptation of employment (e.g. employees to develop and realize the innovation) whereas, on the other hand, innovation may trigger employment because of a higher demand due to a higher competitiveness of the firm. An adequate econometric analysis has to cope with this endogeneity problem. To address the simultaneity problem of employment development and the decision to innovate or not, we apply the so-called endogenous switching regression model (Maddala 1983, Lokshin, Sajaia 2004). The model can be described as follows:

Selection equation that describes the determinants of the decision of a firm to innovate (regime 1) or not (regime 0$)$ :

$$
\begin{aligned}
& \text { Inno }_{\mathrm{i}}=1 \text { if } \gamma \mathrm{Z}_{\mathrm{i}}+\mathrm{u}_{\mathrm{i}}>0 \quad \text { (Innovators) } \\
& \text { Inno }_{\mathrm{i}}=0 \text { if } \gamma \mathrm{Z}_{\mathrm{i}}+\mathrm{u}_{\mathrm{i}} \leq 0 \quad \text { (Non-Innovators) }
\end{aligned}
$$


Continuous equations:

Regime 1: $\quad$ Empdynamic $_{1 \mathrm{i}}=\beta_{1} \mathrm{X}_{1 \mathrm{i}}+\varepsilon_{1 \mathrm{i}}$ if $\mathrm{I}_{\mathrm{i}}=1$

Regime 0: $\quad$ Empdynamic $_{0 \mathrm{i}}=\beta_{0} \mathrm{X}_{0 \mathrm{i}}+\varepsilon_{0 \mathrm{i}}$ if $\mathrm{I}_{\mathrm{i}}=0$

The error term $u_{i}$ is assumed to be correlated with the error terms of the continuous equations, $\varepsilon_{1 \mathrm{i}}$ and $\varepsilon_{2 \mathrm{i}}$.

The dependent variables empdynamic $c_{\mathrm{ji}}(\mathrm{j}=0,1)$ in the continuous equations denote the growth rate of employment from 2006 to 2008 for the two regimes of the selection equation. The dependent variable of the selection equation (inno) gets the value 1 for innovators (product, process or organizational innovators) and 0 otherwise. The endogenous switching model allows integrating different sets of independent variables for the two regimes. This is an important feature because it is possible to include variables such as the type of innovation for innovative firms where there is obviously no variation for non-innovative firms concerning this variable. Our correlated variables $\left(\mathrm{X}_{\mathrm{i}}\right.$ and $\left.\mathrm{Z}_{\mathrm{i}}\right)$ can be described as follows (for an exact definition of the variables see Annex 1):

Perform denotes the growth rate of turnover from 2006 to 2008 as a proxy for product demand. Envprocess and envproduct are dummy variables signifying whether a firm is specialized in environmental process or product innovations, respectively. Rad gets the value 1 if the firm realized internal or external research activities during 2006 and 2008. Highqual represents the share of employees with a university degree in a firm and can be interpreted as an indicator for the technological capability of a firm.

The investment intensity (invintens) is measured by the gross investment 2008 per employee. The dummy variable international captures the geographical orientation of a firm, getting the value 1 if the firm exports goods and/or services to foreign countries.

To capture the influence of the competitive situation on the firms' decision to innovate, we include the dummy variables competition1-4. Competition1 describes the situation if the market position of the firm is highly threatened by new competitors, competition 2 indicates the length of the product life cycle, competition3 gets the value 1 if the firm' products are easily replaceable by those of the competitors and competition 4 captures the competition pressure from foreign competitors. 
Furthermore, control variables such as size (number of employees in 2008), age (age of the firm measured in years) region (dummy for East and West Germany) and sector dummies are included.

As expected from the literature, the results of our endogenous switching model (Table 4) show that innovative firms are characterized by a significantly more dynamic employment development compared to non-innovative firms. This can be verified by the positive and significant correlation coefficient rhol $=0.8$ denoting a positive correlation between $\varepsilon_{1 \mathrm{i}}$ and $\mathrm{u}_{\mathrm{i}}$. An innovative firm shows a better employment development compared to a randomly chosen firm from the whole sample.

A very important result for evaluating the employment effects of eco-innovation is that environmental process innovations seem especially promoting employment confirmed by the significant coefficient of the variable envprocess. This result confirms our theoretical considerations in Section 2: Environmental process innovations induce cost savings (e.g. material and energy savings) then leading to a higher competitiveness (lower prices) and a higher demand. Contrary to that result, environmental product innovations do not seem to trigger employment over-proportionally compared to other innovations.

Customer demand (perform), using the turnover development as a proxy variable, is positively correlated to the employment development for both innovators and non-innovators. More internationally oriented firms are more forced to be innovative showed by the significantly positive sign of the coefficient of international in the selection equation. A higher degree of internationalization is also connected with a higher employment dynamics of the innovative firms. This is also true for the significance of a highly qualified staff. A high qualification (highqual) level triggers the innovativeness of a firm within the selection equation and the employment dynamics of innovative firms.

Younger firms (age) seem to be more innovative connected with a more dynamic employment development for both innovative and non-innovative firms.

Our results for further control variables of the selection equation show that larger firms are more likely to innovate (size). This is also true for West German compared to East German firms (region). The competition conditions also matter for the innovativeness of a firm. A short length of the product life seems to require more innovation activities (competition2). This is also the case for a high competition pressure from foreign competitors (competition4). 
Table 4: Eco-Innovation and Employment: An Endogenous Switching Model

\begin{tabular}{|c|c|c|c|}
\hline $\begin{array}{l}\text { Dependent var } \\
\text { Empdynamic } c_{\mathrm{ji}} \\
\text { two regimes } \\
\text { Inno (selectior }\end{array}$ & $\begin{array}{l}\text { ous equations): Gro } \\
\text { n): } 1 \text { Innovators, } 0 \text { l }\end{array}$ & $\begin{array}{l}\text { rate of employmen } \\
\text { innovators }\end{array}$ & 2006 to 2008 for the \\
\hline Variables & $\begin{array}{l}\text { Empdynamic of } \\
\text { Innovators }\end{array}$ & $\begin{array}{l}\text { Empdynamic of } \\
\text { Non-Innovators }\end{array}$ & Selection equation \\
\hline Age & $-0.06(-2.18)^{*}$ & $-0.07(-2.50)^{* *}$ & $-0.00(-1.88)^{+}$ \\
\hline Competition 1 & - & - & $-0.02(-0.58)$ \\
\hline Competition 2 & - & - & $0.25(5.15)^{* *}$ \\
\hline Competition 3 & - & - & $0.04(1.21)$ \\
\hline Competition4 & - & - & $0.09(2.16)^{*}$ \\
\hline Envprocess & $6.44(1.76)^{+}$ & - & - \\
\hline Envproduct & $-0.92(-0.36)$ & - & - \\
\hline Highqual & $0.25(4.95)^{* *}$ & $-0.07(-1.39)$ & $0.01(6.23)^{* *}$ \\
\hline International & $17.6(7.24)^{* *}$ & $1.32(0.51)$ & $0.51(11.3)^{* *}$ \\
\hline Invintens & $0.00(0.32)$ & $-0.00(-1.93)^{*}$ & - \\
\hline Perform & $0.10(36.27)^{* *}$ & $0.36(18.5)^{* *}$ & - \\
\hline $\operatorname{Rad}$ & $2.59(1.30)$ & - & - \\
\hline Region & - & - & $-0.06(-1.68)^{+}$ \\
\hline Size & $0.00(0.64)$ & $0.00(0.32)$ & $0.00(4.91)^{* *}$ \\
\hline Sec 1 & $-14.3(-1.61)$ & $-15.0(-2.32)^{*}$ & $-0.14(-0.93)$ \\
\hline $\mathrm{Sec} 2$ & $-0.68(-0.12)$ & $-7.53(-1.41)$ & $0.19(1.76)^{+}$ \\
\hline Sec3 & $-5.90(-0.84)$ & $-17.2(-2.53)^{3 *}$ & $-0.02(-0.16)$ \\
\hline $\operatorname{Sec} 4$ & $-7.56(-1.45)$ & $-12.8(-2.87)^{* *}$ & $-0.06(-0.63)$ \\
\hline $\operatorname{Sec} 5$ & $0.32(0.05)$ & $-7.61(-0.86)$ & $0.61(4.22)^{* *}$ \\
\hline Sec6 & $-9.96(-1.48)$ & $-7.11(-1.18)$ & $-0.13(-1.03)$ \\
\hline $\operatorname{Sec} 7$ & $-3.74(-0.52)$ & $-13.0(-1.85)^{+}$ & $0.09(0.68)$ \\
\hline $\operatorname{Sec} 8$ & $2.30(0.46)$ & $-12.2(-2.61)^{* *}$ & $0.13(1.36)$ \\
\hline Sec9 & $18.8(3.73)^{* *}$ & $-10.8(-1.73)^{+}$ & $0.45(4.43)^{* *}$ \\
\hline $\operatorname{Sec} 10$ & $5.56(1.02)$ & $-6.2(-0.93)$ & $0.30(2.65)^{* *}$ \\
\hline Sec11 & $6.74(1.22)$ & $-8.01(-1.09)$ & $0.44(3.62)^{* *}$ \\
\hline Sec12 & $6.51(1.03)$ & $-9.14(-1.20)$ & $0.24(1.84)^{+}$ \\
\hline Sec13 & $-4.76(-0.63)$ & $-15.3(-1.84)^{+}$ & $0.11(0.71)$ \\
\hline Sec14 & $-6.10(-0.52)$ & $-8.25(-0.91)$ & $-0.10(-0.50)$ \\
\hline Sec15 & $-23.2(-3.07)^{* *}$ & $-1.30(-0.27)$ & $-0.43(-3.61)^{* *}$ \\
\hline Sec16 & $-36.9(-3.09)^{* *}$ & $-12.7(-2.26)^{*}$ & $-0.81(-4.77)^{* *}$ \\
\hline $\operatorname{Sec} 17$ & $-16.3(-2,54)^{* *}$ & $-9.52(-2.21)^{*}$ & $-0.50(-4.80)^{* *}$ \\
\hline Sec18 & $-4.93(-0.92)$ & $-11.2(-2.85)^{* *}$ & $-0.29(-3.24)^{* *}$ \\
\hline Sec19 & $-4.68(-0.76)$ & $-9.67(-1.91)^{+}$ & $0.05(0.47)$ \\
\hline $\operatorname{Sec} 20$ & $-3.19(-0.72)$ & $-8.45(-2.11)^{*}$ & $0.8(1.00)$ \\
\hline $\begin{array}{l}\text { Endogenous } \\
\text { theses. Walc } \\
\text { spectively. R } \\
\text { LR test of in }\end{array}$ & $\begin{array}{l}\text { odel. Number of } \\
400 .{ }^{+*},{ }^{* *} \text { den } \\
\text { rho }{ }_{1}=0.81^{* *} \cdot C \\
\text { uations: } \mathrm{Chi}^{2}=\end{array}$ & $\begin{array}{l}\text { ations: } 4,535 . \mathrm{Z}-\mathrm{s} \\
\text { ificance a } \mathrm{t} \text { the } \\
\text { s are not reported }\end{array}$ & $\begin{array}{l}\mathrm{s} \text { are given in paren- } \\
\% \text { and } 1 \% \text { level, re- }\end{array}$ \\
\hline
\end{tabular}




\subsection{Employment effects of different environmental innovation fields}

In Section 4.1, the employment effects of eco-innovations compared to other innovations and to firms without innovative activities were analyzed. In the following, we try to go more into detail by analyzing the employment effects of different eco-innovation fields. Since the overall effects of eco-innovations on the growth rate of employment within the questioned firms are relatively low, we restrict our analysis to the question if a certain type of eco-innovation is correlated to a positive employment development or not. Therefore, we use a dummy variable getting the value 1 if a firm realized a positive employment development from 2006 to 2008 and zero otherwise. Furthermore, we restrict our sample of firms to those having realized an eco-innovation.

Due to the binary character of our dependent variable empdynamicbin, we use a binary probit model: The firm has to decide whether to increase employment (empdynamicbin $=1$ ), or to reduce or keep employment constant $(\mathrm{Y}=0)$. Following our theoretical considerations in Section 2, we believe that different factors such as the introduction of different eco-innovations, the demand for eco-innovative products or control variables such as the size of the firm summarized by a vector $\mathbf{x}$ influence this decision. Therefore, we need an estimation of the probability

Prob (empdynamicbin $=1 \mid \mathbf{x})=\mathrm{F}(\mathbf{x}, \beta)$.

The probit model assumes the normal distribution: Prob (empdynamicbin $=1 \mid \mathbf{x})=\Phi\left(\mathbf{x}^{\prime} \beta\right)$.

The parameters $\beta$ reflect the impact of changes in $\mathrm{x}$ on the probability (Greene, 2008: 772). We calculate marginal effects that allow comparing the influence of the different environmental innovation areas.

Besides the variables already described in Section 4.1, we use indicators for different types of eco-innovations. Materialenergy captures environmental innovations within the firm leading to a high reduction of material and energy use and $\mathrm{CO}_{2}$-emissions. Airwater, soilnoise and dangrecyc represent the respective variables for other air emissions and water pollution, soil and noise pollution, dangerous substances and recycling. Envproduct denotes environmental product innovations with highly positive environmental effects. Regulations as determinant of eco-innovations are represented by present and future, anticipated regulations. Furthermore, 
environmentally related subsidies (envsubsidies), customer demand and the self-commitment of the respective branch as determinants for eco-innovations are considered.

Table 5: Employment effects of different environmental innovation fields

\begin{tabular}{|c|c|c|c|}
\hline \multicolumn{4}{|c|}{ Dependent variable: Empdynamicbin } \\
\hline \multicolumn{4}{|c|}{ Increasing employment from 2006 to 2008} \\
\hline \multicolumn{4}{|c|}{ Constant or decreasing employment from 2006 to 2008} \\
\hline \multicolumn{4}{|l|}{ Correlates } \\
\hline Types of Eco-innovation & & Sector dummies & \\
\hline Airwater & $-0.06(-1.84)^{+}$ & Sec1 & $-0.18(-2.63)^{* *}$ \\
\hline Materialenergy & $0.05(1.97)^{*}$ & $\operatorname{Sec} 2$ & $-0.07(-1.54)$ \\
\hline Soilnoise & $0.06(1.60)$ & Sec3 & $-0.28(-4.96)^{* *}$ \\
\hline Dangrecyc & $0.03(1.02)$ & Sec4 & $-0.13(-3.03)^{* *}$ \\
\hline \multirow[t]{3}{*}{ Envproduct } & $0.01(0.48)$ & Sec5 & $-0.15(-2.91)^{* *}$ \\
\hline & & Sec6 & $-0.15(-2.95)^{* *}$ \\
\hline & & Sec7 & $-0.12(-2.10)^{*}$ \\
\hline \multirow{3}{*}{$\begin{array}{l}\text { Determinants of eco- } \\
\text { innovation }\end{array}$} & & Sec8 & $0.02(0.51)$ \\
\hline & & Sec9 & $0.07(1.58)$ \\
\hline & & Sec10 & $-0.07(-1.61)$ \\
\hline Present regulations & $0.03(1.26)$ & Sec11 & $-0.07(-1.53)$ \\
\hline Future regulations & $-0.03(-1.48)$ & Sec12 & $-0.04(-0.79)$ \\
\hline EnvSubsidies & $0.02(0.57)$ & Sec13 & $-0.20(-3.24)^{* * *}$ \\
\hline Demand & $0.07(3.20)^{* *}$ & Sec14 & $-0.00(-0.05)$ \\
\hline Self commitment & $-0.06(-3.20)^{* *}$ & Sec15 & $-0.12(-2.22)^{*}$ \\
\hline \multirow[t]{2}{*}{$\operatorname{Rad}$} & $0.09(4.88)^{* *}$ & Sec16 & $-0.26(-3.44)^{* * *}$ \\
\hline & & Sec17 & $-0.05(-1.10)$ \\
\hline \multirow[t]{2}{*}{ Control variables } & & Sec18 & $0.03(0.62)$ \\
\hline & & Sec19 & $-0.14(-2.55)^{* *}$ \\
\hline International & $0.15(7.92)^{* *}$ & Sec20 & $-0.12(-3.01)^{* *}$ \\
\hline Size & $0.00(1.48)$ & & \\
\hline \multicolumn{4}{|c|}{$\begin{array}{l}\text { Probit regression reporting marginal effects. Number of observations: } 3,706 . \text { Z-statistics are given in } \\
\text { parentheses. LR } \mathrm{Chi}^{2}(62)=314 \text {. Pseudo } \mathrm{R}^{2}=0.06 .^{+*},{ }^{* *} \text { denote significance at the } 10 \%, 5 \% \text { and } 1 \% \\
\text { level, respectively. } \\
\text { The marginal effects for the continuous independent variables were calculated at their means. Concerning } \\
\text { dummy variables the values report the change in probability for a discrete change of the dummy variable } \\
\text { from } 0 \text { to } 1 \text {. Sector dummies are not reported. Only environmental innovative firms are included. }\end{array}$} \\
\hline
\end{tabular}

Consistent with the results in Section 4.1, the estimation of our probit model shows that material and energy savings are positively correlated to employment (materialenergy). Material and energy savings induce cost savings leading to a higher competitiveness of the firm. The increased competitiveness then leads to a higher demand and more employment. This result is in line with the famous Porter hypothesis (see also Section 2) and with Rexhäuser, Rammer (2011) detecting a positive relationship between the realization of material and energy savings and the profitability of the firm. On the other side, air and water process innovations (air- 
water), where end-of-pipe technologies are dominating, are slightly negatively significant. Product innovations (envproduct) are again not significant. If customer demand is especially relevant for the realization of eco-innovations, the employment performance of the firm is better - not a surprising result because these innovations are mainly introduced to increase the performance and the profitability of a firm. In firms where eco-innovations are driven by regulations and subsidies there is not a better employment performance noticeable and firms where self-commitments of the respective branch are an important factor for eco-innovations, the employment performance seems to be even worse. Internationally oriented and R\&D intensive firms also have a better employment performance confirming our results in Section 4.1 .

\section{Summary}

Due to the fact that environmental technologies from end-of-pipe to cleaner technologies are not homogenous, an analysis of the employment effects differentiating between different environmental technology fields seems to be necessary. Nevertheless, there are only few studies in the literature because of the lack of adequate data. We use the 2009 wave of the German part of the Community Innovation Panel (CIS) allowing for such an analysis at the firm level. The main focus of the analysis lies on the adaptation behavior of firms with respect to the relationship of employment and (environmental) innovation. We use an endogenous switching regression approach to take the simultaneous character of innovation activities and employment demand into consideration.

A descriptive analysis shows that firms having realized environmental process innovations are characterized by a much higher employment dynamic. The theoretical background of this finding is that e.g. material and energy saving process innovations induce cost-savings which lead to a higher competitiveness (due to a higher productivity accompanied by a given output) and a higher demand resulting in an increase of employment. Our econometric analysis confirms this result showing that innovative firms are characterized by a significantly more dynamic employment development compared to non-innovative firms. Especially the realization of environmental process innovations leads to a higher employment within the firm. Furthermore, the employment dynamics and the innovativeness of a firm are positively correlated to their export performance and the average qualification level of the firms' staff.

A more detailed analysis by different environmental innovation fields shows that material and energy savings are positively correlated to employment because they help to increase the prof- 
itability and competitiveness of the firm. On the other side, air and water process innovations that are still dominated by end-of-pipe technologies have a negative impact on the employment development. On the one hand, the introduction of end-of-pipe technologies requires additional staff, but, on the other hand, leads to higher costs accompanied by negative employment effects. According to our empirical results, the second effect seems to be stronger.

In a nutshell, the employment effects of the introduction of cleaner technologies seem to be more advantageous within a firm compared to more end-of-pipe oriented technologies.

\section{References}

Antonucci, T., M. Pianta (2002), Employment Effects of Product and Process Innovation in Europe. International Review of Applied Economics 16 (3): 295-307.

Bijman, P., P. Nijkamp (1988), Innovation, environmental policy and employment: an exploratory analysis. Zeitschrift für Umweltpolitik und Umweltrecht (ZfU) 11/1988: 81-92.

Bogliacino, F., Pianta, M. (2010), Innovation and Employment: A Reinvestigation using Revised Pavitt Classes. Research Policy, Vol. 39, Issue 6: 699-842.

Brenke, K. (2009): Reallöhne in Deutschland über mehrere Jahre rückläufig. Wochenbericht des Deutschen Instituts für Wirtschaftsforschung (DIW) Nr. 33/2009.

Entorf, H., W. Pohlmeier (1990), Employment, Innovation and Export Activity: Evidence from Firm-level Data, p. 394-415. In: Florens, J.-P., M. Ivaldi, J.-J. Laffont, F. Laisney (eds): Microeconometrics: Surveys and Applications. Basil Blackwell. Oxford 1990.

Greenan, N., D., Guellec (2000), Technological innovation and employment reallocation. Labour: Review of Labour Economics and Industrial Relations. Vol. 14 (2000). No. 4: $547-$ 590.

Greene, W. H. (2008), Econometric Analysis. Sixth Edition. Pearson Education International. New Jersey.

Hall, B. H., F. Lotti, J. Mairesse (2006), Employment, Innovation and Productivity: Evidence from Italian Microdata. The Institute for Fiscal Studies. Working Paper 24/2006, London.

Harabi, N. (2000), Employment Effects of Ecological Innovations: An Empirical Analysis. Discussion Paper 07/2000 of the University of Solothurn. Solothurn.

Harrison, R., J. Jaumandreu, J. Mairesse, B. Peters (2008), Does Innovation Stimulate Employment? A Firm-Level Analysis Using Comparable Micro-Data From Four European Countries, ZEW Discussion Paper 08-111. Mannheim. 
Horbach, J. (2010): The Impact of Innovations Activities on Employment in the Environmental Sector - Empirical Results for Germany at the Firm Level. In: Journal of Economics and Statistics, Vol. 230/4:403-419.

Lachenmaier, S., H. Rottmann (2007), Employment Effects of Innovation at the Firm Level. Jahrbücher für Nationalökonomie und Statistik 227: 254-272.

Lachenmaier, S., H. Rottmann (2011), Effects of Innovation on Employment: A Dynamic Panel Analysis. International journal of industrial organization. Vol. 29.2011, 2: 210-220.

Lokshin, M., Sajaia, Z. (2004): Maximum likelihood estimation of endogenous switching regression models. The Stata Journal 4, Number 3: 282-289.

Maddala, G. S. (1983), Limited-Dependent and Qualitative Variables in Econometrics. Cambridge University Press. Cambridge.

Peters, B. (2005), Employment Effects of Different Innovation Activities: Microeconometric Evidence for Germany. ZEW Discussion Paper 04-73. Mannheim.

Pfeiffer, Friedhelm, Klaus Rennings (2001): Employment Impacts of Cleaner Production Evidence from a German Study Using Case Studies and Surveys. In: „Business Strategy and the Environment", Vol. 10, Number 3: 161-175.

Pianta, M. (2000), The Employment Impact of Product and Process Innovations. In: Vivarelli, M., M. Pianta (eds.) (2000), The Employment Impact of Innovation. Evidence and Policy. Routledge. London: 77-95.

Piva, M., M. Vivarelli (2005), Innovation and Employment: evidence from Italian Microdata. Journal of Economics, Vol. 86 (2005), No. 1: 65-83.

Porter, M. E., C. van der Linde (1995), Toward a New Conception of the EnvironmentCompetitiveness Relationship. Journal of Economic Perspectives 9, No. 4: 97-118.

Rennings, Klaus, Thomas Zwick (2002): The Employment Impact of Cleaner Production on the Firm Level - Empirical evidence from a Survey in Five European Countries. International Journal of Innovation Management (IJIM), Special Issue on „The Management of Innovation for Environmental Sustainability“, Vol. 6, No. 3: 319-342.

Rennings, K. (2003): Employment Impacts of Cleaner Production. Physica-Verlag, Heidelberg.

Rennings, K., Ziegler, A., Zwick, T. (2004): The Effect of Environmental Innovations on Employment Changes: An Econometric Analysis. Business Strategy and the Environment 13: 374-387.

Rexhäuser, S., Rammer, C. (2011): Unmasking the Porter Hypothesis: Environmental Innovations and Firm-Profitability, ZEW Discussion Paper No. 11-036, Mannheim. 
Rottmann, H., M. Ruschinski (1998), The Labour Demand and the Innovation Behaviour of Firms - An Empirical Investigation for West-German Manufacturing Firms. Jahrbücher für Nationalökonomie und Statistik 217: 741-752.

RWI (Rheinisch-Westfälisches Institut für Wirtschaftsforschung) (2005), Beschäftigungswirkungen von Forschung und Innovation. Forschungsvorhaben im Auftrag des Bundesministeriums für Wirtschaft und Arbeit. Essen.

Smolny, W. (1998), Innovations, prices and employment: a theoretical model and an empirical application for West German manufacturing firms. The Journal of Industrial Economics. Vol. 46 (1998), No. 3: 359-381.

Smolny, W., T. Schneeweis (1999), Innovation, Wachstum und Beschäftigung: Eine empirische Untersuchung auf der Basis des ifo Unternehmenspanels. Jahrbücher für Nationalökonomie und Statistik 218: 453-472.

Smolny, W. (2002), Employment adjustment at the firm level: a theoretical model and an empirical investigation for West German manufacturing firms. Labour: Review of Labour Economics and Industrial Relations. Vol. 16 (2002): 65-88.

Statistisches Bundesamt (2011): Inlandsproduktberechnung - Lange Reihen, Wiesbaden, http://www.destatis.de/jetspeed/portal/cms/Sites/destatis/Internet/DE/Content/Statistiken/V olkswirtschaftlicheGesamtrechnungen/Inlandsprodukt/Tabellen/Tabellenuebersicht.psml.

Van Reenen, J. (1997), Employment and technological innovation: evidence from UK manufacturing firms. Journal of labor economics 15 (1997). No. 2: 255-284.

Vernon, R. (1966), Investment and International Trade in the Product Cycle. Quarterly Journal of Economics 80: 190-207.

Zimmermann, V. (2009), The impact of innovation on employment in small and medium enterprises with different growth rates. Journal of Economics and Statistics 229: 313-326. 
Appendix 1: Definition of variables and descriptive statistics

\begin{tabular}{|c|c|c|c|}
\hline Variable & Description & Mean & St.Dev. \\
\hline \multicolumn{4}{|c|}{ Endogenous variables } \\
\hline Empdynamic & Growth rate of employment within the firm from 2006 to 2008 , in $\%$ & 11.0 & 72.5 \\
\hline Empdynamicbin & 1 Increasing employment, 0 Constant or decreasing employment & 0.54 & 0.50 \\
\hline Inno & 1 Innovator, 0 No innovator & 0.62 & 0.49 \\
\hline \multicolumn{4}{|l|}{$\begin{array}{l}\text { Types of Eco- } \\
\text { Innovation }\end{array}$} \\
\hline Envprocess & 1 Process innovations with high environmental impact, 0 Other & 0.06 & 0.24 \\
\hline Envproduct & 1 Product innovations with high environmental impact, 0 Other & 0.14 & 0.35 \\
\hline Airwater & 1 High reduction of air and water related emissions, 0 Other & 0.09 & 0.28 \\
\hline Dangrecyc & 1 High reduction of dangerous substances and recycling, 0 Other & 0.11 & 0.32 \\
\hline Materialenergy & 1 High reduction of material, energy use and $\mathrm{CO}_{2}$ emissions, 0 Other & 0.15 & 0.36 \\
\hline Soilnoise & 1 High reduction of soil and noise pollution, 0 Other & 0.06 & 0.23 \\
\hline \multicolumn{4}{|l|}{ Determinants } \\
\hline Present regulations & Fulfilment of present laws and standards ( 1 yes, 0 no) & 0.32 & 0.47 \\
\hline Future regulations & Anticipation of future regulations ( 1 yes, 0 no) & 0.27 & 0.44 \\
\hline EnvSubsidies & Public support of eco-innovations ( 1 yes, 0 no) & 0.10 & 0.30 \\
\hline Demand & Customer demand for eco-innovations ( 1 yes, 0 no) & 0.27 & 0.45 \\
\hline Self-commitment & Self-commitments of the branch ( 1 yes, 0 no) & 0.28 & 0.45 \\
\hline & 1 highly relevant, 0 other: & & \\
\hline Competition1 & Market position threatened by entry of new competitors & 0.36 & 0.48 \\
\hline Competition2 & Products and services are rapidly obsolete & 0.18 & 0.38 \\
\hline Competition3 & Products and services are easily replaceable by competitors & 0.51 & 0.50 \\
\hline Competition4 & High competition intensity by foreign firms & 0.33 & 0.47 \\
\hline Highqual & Share of employees with university degree 2008 in \% & 20.3 & 25.1 \\
\hline International & 1 Exports to other (EU) countries, 0 No exports & 0.46 & 0.50 \\
\hline Invintens & Gross investment 2008 per employee, in 1000 EUR & 26.3 & 366.3 \\
\hline Perform & Growth rate of turnover from 2006 to 2008 , in $\%$ & 31.8 & 552.1 \\
\hline $\operatorname{Rad}$ & 1 Internal or external R\&D, 0 No $R \& D$ activities & 0.61 & 0.49 \\
\hline \multicolumn{4}{|l|}{ Control variables } \\
\hline Age & Age of the firm $(2008-$ year of foundation +0.5$)$ & 31.8 & 38.3 \\
\hline Region & 1 East Germany, 0 West Germany & 0.31 & 0.46 \\
\hline Size & Number of employees 2008 & 578.7 & 9551.6 \\
\hline Sec1 & Agriculture, mining, quarrying of stones & 0.02 & 0.13 \\
\hline $\operatorname{Sec} 2$ & Food products and beverages, tobacco & 0.05 & 0.21 \\
\hline Sec3 & Textiles, leather & 0.03 & 0.17 \\
\hline $\operatorname{Sec} 4$ & Processing of wood, paper, printing & 0.06 & 0.24 \\
\hline $\operatorname{Sec} 5$ & Chemical Industry & 0.04 & 0.18 \\
\hline Sec6 & Rubber and plastic products & 0.03 & 0.17 \\
\hline Sec7 & Glass, ceramics & 0.02 & 0.15 \\
\hline $\operatorname{Sec} 8$ & Basic metals and fabricated metals & 0.07 & 0.25 \\
\hline Sec9 & Machinery & 0.07 & 0.25 \\
\hline $\operatorname{Sec} 10$ & Electrical machinery and apparatus & 0.05 & 0.21 \\
\hline Sec11 & Precision and optical instruments & 0.04 & 0.20 \\
\hline $\operatorname{Sec} 12$ & Motor vehicles, other transport equipment & 0.03 & 0.17 \\
\hline $\operatorname{Sec} 13$ & Furniture & 0.02 & 0.14 \\
\hline Sec14 & Recycling, waste and waste water removal & 0.01 & 0.10 \\
\hline $\operatorname{Sec} 15$ & Energy and water supply & 0.04 & 0.19 \\
\hline Sec16 & Construction sector & 0.02 & 0.13 \\
\hline
\end{tabular}




\begin{tabular}{|l|l|c|c|}
\hline Sec17 & Wholesale and retail trade & 0.05 & 0.22 \\
Sec18 & Transport and communication, & 0.08 & 0.26 \\
Sec19 & Banking sector, assurances, renting of cars and other products & 0.05 & 0.21 \\
Sec20 & Data processing, research and development, consulting & 0.14 & 0.35 \\
Sec21 & Other services & 0.12 & 0.32 \\
\hline
\end{tabular}

